\title{
Expediency of the reconstruction of drainage systems
}

Vidmantas Gurklys, Algis Kvaraciejus

Aleksandras Stulginskis University

E-mail: vidmantas.gurklys@asu.lt; algis.kvaraciejus@asu.lt
In Lithuania, originally wet and swampy lands cover about 3.5 million hectares. By 20112.98 million hectares of wet and waterlogged lands, of which 2.58 million ha are agricultural lands, were drained in Lithuania. Lately, because of social, demographic and economic reasons, significant areas of drained lands were no longer used in agricultural production, they became neglected and drainage systems became unsupervised. Around 7\% of drained areas in Lithuania are of poor reclamation condition because of defective drainage systems. The major investment is necessary for their reconstruction therefore it is so important to define the expediency of restoration.

Areas, where it is appropriate / inappropriate to restore drainage systems (depending on the economic benefits derived from agricultural production and rural development strategies), are set out in the paper.

Key words: drained land, technical condition, increase productivity, economic expediency

\section{INTRODUCTION}

The Republic of Lithuania is in the temperate zone, where agricultural production is highly dependent on natural and climatic conditions. Although these conditions allow receiving quite good yields of majority of plants used for human consumption, yet yield stability in the current conditions would permit the country and its farmers' competitiveness in Europe and the world (Long-term Development..., 2002). Unfortunately, the volatility in natural conditions (significant fluctuations in the falling rain and the distribution parameters, the volatility of the number of sunny days, the total annual variable positive temperature parameters) forced the country to take measures to mitigate this risk.

The most important risk reduction measure, the most widely used in the country - land drainage - has significant control of individual rain falling and the distribution parameters and their effect on plant growth, and thus of total agricultural production (Baubinas, 1997). Until 1990 Lithuania has drained around 3 million hectares (nearly 80 percent of agricultural land) necessary to drain the soil, significantly reducing the unfavorable natural and climatic conditions of risk (Database..., 2008). Currently, by January 1, 2012, the total floor area of drained land made up 2.98 million ha, including 2.58 million ha of agricultural land (The Technical Assessment..., 2007).

Changed legal-economic situation in the country and the agricultural transition caused the change of the legal status of drainage systems - they still belonged to the state, but individuals have become their users (farmers and other agricultural entities). In consequence of inadequate legal status of drainage systems property and use and reduced financial capacities, drainage systems have become unsupervised, their technical condition deteriorated significantly on a local basis. Meanwhile, the country's natural climatic conditions are still problematic for land drainage and remain one of the most important agricultural production risks (Bastienè, Buožis, 2001). 
The aim of this paper is to assess appropriateness of restoration of poor condition drainage systems using the technical and social-economical criteria and to provide a summary of information from publicly available databases. This determined the following tasks:

1) systematic information on the current technical condition of drainage systems at the level of neighborhoods;

2) methodological reasoning of strategic and economic criteria for appropriateness of reconstruction of drainage systems;

3) rehabilitation of drainage systems to determine the appropriateness of the technical, economic and social terms, to submit the findings to the Geographic Information System (GIS) database.

\section{METHODOLOGY OF RESEARCH}

The aim of the research was to combine the general expediency reasonings of the reconstruction (renovation) of existing drainage systems and recommend priorities of the reconstruction (renovation) of drainage systems according to scientifically based complex criteria.

In order to achieve this goal the following information concerning these parameters was analysed and evaluated:

- the present technical condition of drainage systems in different municipalities;
- the planned land use strategy;

- the real economic benefits of drained land.

In order to assess changes of the use of reclaimed lands and drainage structures over the past decade as well as to fix their condition and clarify the reclaimed areas the technical assessment of the condition of reclaimed lands and drainage structures was carried out in 2006 following Order No. 3D-51 of the Minister of Agriculture on 8 February 2006 (The Technical Assessment..., 2007).

Information on the reclaimed areas in cadastral localities, existing reclamation projects, condition of reclaimed areas, opportunities for rehabilitation of drainage systems is presented in the graphical and attributes part of the database Mel_DB10LT.

Information is presented on individual GIS layers (criteria), at country's sub-district level. One could be able to judge about the expediency (or non-expediency) of the reconstruction (renovation) of the drainage systems of poor condition only by the significance of expected land-use strategies and cost-benefit criteria (FADN..., 2008).

Figure 1 shows the territory of the cadastral area the condition of reclaimed areas of which is defined and divided into the good and poor reclamation condition.

Results of the scientific work may be used by operators and authorities of the country interested in the use of drained lands.

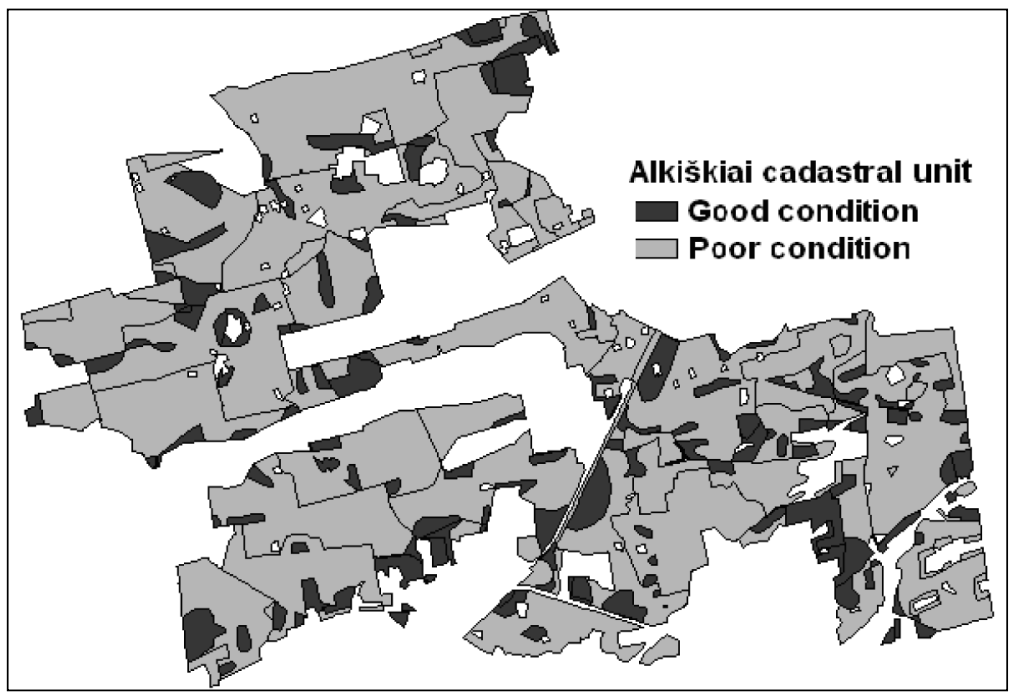

Fig. 1. Assesment of the condition of the reclaimed areas in the Alkiškiai cadastral unit (Database..., 2008) 


\section{RESULTS}

The areas of poor reclamation condition make up 7 percent from the Lithuania's reclaimed areas (208 600 ha) and are distributed unevenly in municipalities (Fig. 2).

The prevailing reason for the poor reclamation condition is the poor technical condition of drainage systems (Bastiené, Buožis, 2001), what makes up 60 percent from the total area of the poor reclamation condition, therefore it is important to determine the expediency of their renovation as well as the sequence based on strategic, economic and social criteria.

The suitability of the territories for agricultural production is one of the most important selection criteria measures necessary for the differentiation of the justification of the development of rural areas (Baubinas, 1997).

Natural soils have a significant effect on the agricultural achievements. Two natural zones, which are characterized by 15-agronomic soil areas, are distinguished according to soils, relief, rainfall and its distribution during the year. In the zones of West and East Lithuania soils of lower economic value are prevailing, more than a quarter of soils are low nitrogen ones. The Middle Lithuanian zone is the largest of all, soils are the most fertile here and all plants grow very well. The index of less-favored lands (where the agricultural productivity point reaches 32 and less) best reflects natural differences of the regions in terms of the problematicity of agricultural development. When farming in less-favored agricultural conditions, income often does not cover the cost of production, therefore state aid to producers, especially to those wanting to engage in other activities, is necessary.

The National Rural Development Strategy for 2007-2013, accepted on July 18, 2007 (The National Strategy Plan..., 2007), states that conditions for the rational land use first of all should be created in the most-favored agricultural regions. In the sector of primary agricultural production, farm technologies, modernization level and infrastructure should be improved. While in less-favored areas, where arable land does not suit for further traditional agricultural production, it is appropriate to encourage and support other alternative activities, i. e. afforestation, crafts and rural tourism development, etc.

Similar land-use provisions are also in the General Plan of the Republic of Lithuania. The country's agro-use policy in the General Plan of the Republic of Lithuania primarily seeks to harmonize the basic industries of production farms with natural conditions best suited to agri-business specialization. Agrarian land-use changes are expected in agricultural subjects consistently specializing in agricultural products necessary in our country and demand in foreign markets. 7 agrarian zones

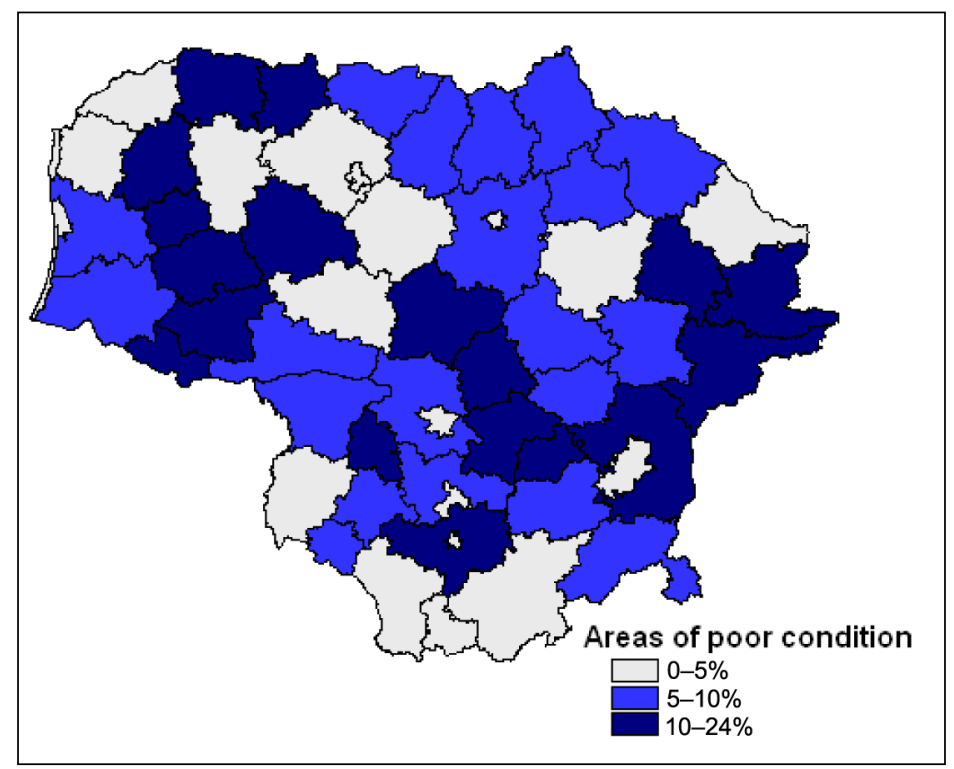

Fig. 2. Reclaimed lands of poor condition in municipalities (Database..., 2008) 
of different potential were identified for the territorial differentiation of the agrarian areas management in the country. The development of agrarian areas in the zones was differentiated according to land use conditions and socio-economic factors (Table 1).

Explanation of indices: $\mathrm{T}$ - territory is used for the growing of agricultural production: $\mathrm{T}_{1}$ - large (agricultural farming lands make up more than $55 \%$ of the territory), $\mathrm{T}_{2}$ - average (agricultural farming lands make up $40-54 \%$ of the territory), $\mathrm{T}_{3}$ - small (agricultural farming lands make up to $40 \%$ of the territory). E - soil sensitivity for the intense land cultivation: $\mathrm{E}_{1}$ - less sensitive, $\mathrm{E}_{2}$ - sensitive to water erosion, $\mathrm{E}_{3}$ - sensitive to wind erosion.

D - productivity of agricultural farming lands: $\mathrm{D}_{1}$ - productive lands (when productivity is 40 points or more), $\mathrm{D}_{2}$ - medium-productive lands (when productivity 33-39 points), $\mathrm{D}_{3}$ - unproductive lands (productivity up to 32 points).

$\overline{\mathrm{U}}$ - conditions for the formation of perspective agricultural structures: $\overline{\mathrm{U}}_{1}$ - favourable conditions to form large farms, $\bar{U}_{2}-$ favourable conditions to form medium-sized and small farms, $\bar{U}_{3}$ - possibility to coordinate farms of various sizes and types.

Specialization directions (in capital letters - the main branch of economy, in small letters - ancillary or supplementary branch of economy): K, $\mathrm{k}$ - wheat cultivation; J, $\mathrm{j}$ - cultivation of other crops; B, b - potatoes; C, c - sugar beet growing; L, 1 - flax cultivation; $\mathrm{R}, \mathrm{r}$ - rapeseed cultivation; $\check{Z}, \check{z}$ - herbaceous forage production; $\mathrm{P}, \mathrm{p}$ - dairy cattle field; G, g - beef cattle; Kl, kl - pig breeding; nt - non-traditional agricultural industries; al - alternative (non-agricultural) activities.

$\mathrm{N}$ - measures to regulate land use: $\mathrm{N}_{1}$ - all agricultural land is maintained and improved, $\mathrm{N}_{2}$ - maintenance and improvement of arable land and drained meadows and pastures, $\mathrm{N}_{3}$ - maintenance and improvement of high-performance arable land soils; larger areas of potential forest plantings.

Summing up the above agricultural development strategy statements, provisions of the General Plan of the Republic of Lithuania, concerning long-term land-use issues as well as the existing particularity of territorial differentiation according to the favor of agricultural activities at the sub-district level, one can distinguish the following agricultural land use zones:

1) intensive use for the commodity field crops, dairy and pig production;

2) moderate use for the production of feed and meat and milk cattle;

3) extensive use, mainly for livestock grazing in meadows and pastures;

4) alternative use, the development of non-traditional industries, alternative activities and afforestation.

Table 1. The zones of the agrarian differentiation established according to agricultural specialization

\begin{tabular}{|c|c|c|c|c|c|c|}
\hline \multirow{2}{*}{$\begin{array}{l}\text { Number } \\
\text { of zones }\end{array}$} & \multirow{2}{*}{ The name of zone } & \multirow{2}{*}{$\begin{array}{c}\text { Area } \\
\mathbf{k m}^{2}\end{array}$} & \multirow{2}{*}{$\begin{array}{l}\text { The indices } \\
\text { of land use } \\
\text { condition }\end{array}$} & \multicolumn{2}{|c|}{$\begin{array}{l}\text { Recomended agricultural } \\
\text { specialization }\end{array}$} & \multirow{2}{*}{$\begin{array}{l}\text { Recomended } \\
\text { land use }\end{array}$} \\
\hline & & & & $\begin{array}{l}\text { Crop industries } \\
\text { and alternatives }\end{array}$ & $\begin{array}{l}\text { Livestock } \\
\text { industry }\end{array}$ & \\
\hline I & $\begin{array}{l}\text { The Southeastern Lithu- } \\
\text { anian zone }\end{array}$ & 772 & $\mathrm{~T}_{3} \mathrm{E}_{3} \mathrm{D}_{3} \overline{\mathrm{U}}_{3}$ & $\mathrm{~J}, \mathrm{~B}, \mathrm{al}$ & $\mathrm{Kl}, \mathrm{p}, \mathrm{nt}$ & $\mathrm{N}_{3}$ \\
\hline II & The Baltic Highlands zone & 1239 & $\mathrm{~T}_{2} \mathrm{E}_{2} \mathrm{D}_{2} \overline{\mathrm{U}}_{2}$ & $\check{Z}, \mathrm{j}$, al & $\mathrm{P}, \mathrm{G}, \mathrm{nt}$ & $\mathrm{N}_{3}$ \\
\hline III & $\begin{array}{l}\text { The Aukštaitija and } \\
\text { Dzūkija plateau zone }\end{array}$ & 692 & $\mathrm{~T}_{1} \mathrm{E}_{1} \mathrm{D}_{2} \overline{\mathrm{U}}_{3}$ & $\mathrm{~J}, \check{z}$, al & $\mathrm{P}, \mathrm{kl}$ & $\mathrm{N}_{2}$ \\
\hline IV & $\begin{array}{l}\text { The Middle Lithuanian } \\
\text { zone }\end{array}$ & 2426 & $\mathrm{~T}_{1} \mathrm{E}_{1} \mathrm{D}_{1} \overline{\mathrm{U}}_{1}$ & $K, C, L, R, j$ & $\mathrm{P}, \mathrm{Kl}$ & $\mathrm{N}_{1}$ \\
\hline V & $\begin{array}{l}\text { The Žemaitija plateau } \\
\text { zone }\end{array}$ & 647 & $\mathrm{~T}_{1} \mathrm{E}_{1} \mathrm{D}_{2} \overline{\mathrm{U}}_{3}$ & $\mathrm{~J}, \mathrm{~b}, \mathrm{l}$ & $\mathrm{P}, \mathrm{g}, \mathrm{kl}$ & $\mathrm{N}_{2}$ \\
\hline VI & $\begin{array}{l}\text { The Žemaitija Highlands } \\
\text { zone }\end{array}$ & 242 & $\mathrm{~T}_{2} \mathrm{E}_{2} \mathrm{D}_{3} \overline{\mathrm{U}}_{2}$ & $\check{Z}, \mathrm{j}, \mathrm{al}$ & $\mathrm{G}, \mathrm{p}, \mathrm{kl}$ & $\mathrm{N}_{3}$ \\
\hline VII & $\begin{array}{l}\text { The zone of the Nemunas } \\
\text { and Pajūris Lowlands }\end{array}$ & 512 & $\mathrm{~T}_{1} \mathrm{E}_{3} \mathrm{D}_{2} \overline{\mathrm{U}}_{1}$ & $\mathrm{~B}, \mathrm{~J}, \mathrm{z}$, al & $\mathrm{P}, \mathrm{Kl}, \mathrm{nt}$ & $\mathrm{N}_{2}$ \\
\hline
\end{tabular}


Based on the above economic indicators Lithuania is divided into separate agricultural development favored or fitness zones. In order for the information collected could be used for various purposes, it is appropriate to divide the territory of Lithuania into separate zones according to favor or suitability for agricultural development, evaluation, also taking into account development strategy (Fig. 3).

In view of the areas favored agricultural development, development strategy, it can be said that in the areas where rural development strategy provides an alternative and extensive agricultural land use, the restoration / renovation of drainage systems is inappropriate.

Agricultural production in drained areas depends on the potential productivity of soils (conditioned by soil mechanical composition, nutrients in the soil and grown field crops structure) as well as on people's efforts to create additional conditions for plant growth (installation of drainage systems) (Šaulys, Bastienè, 2007).

Due the heterogeneity of the soil surface drainage efficiency in various areas of the country considerably differs. Drained soddy gley and glay loam as well as clay soils were given the highest additional points (24). The same soddy gley light textured soils improve (after draining) by $10-15$ points. Soddy calcareous loam and clay soils improve only by 3 points, and soils of light mechanical composition are not improved at all because the drainage does not benefit here.

Soil-point increase due to the drainage is presented in Fig. 4. For example, the agricultural productivity of the agricultural land in the Šalčininkai District has increased (due to drainage) only by 7.2 points, and in the Pakruojis District it increased even by 21.4 points (Maziliauskas et al., 2007). Most of the drained land productivity increases in the central region of Lithuania, which is dominated by heavy textured soils (loams and clays). The drainage of light textured soils (sand and sandy loam) has a much smaller effect on their productivity.

The productivity of land, soil scoring points in the population and the increase of soil drainage, and the whole complex of economic factors affect the intensity of the use of drainage systems.

Such indicators as gross output, net value added (without subsidies) and profit (without subsidy) per 1 ha of agricultural land and 1 hectare of grade most comprehensively show economic

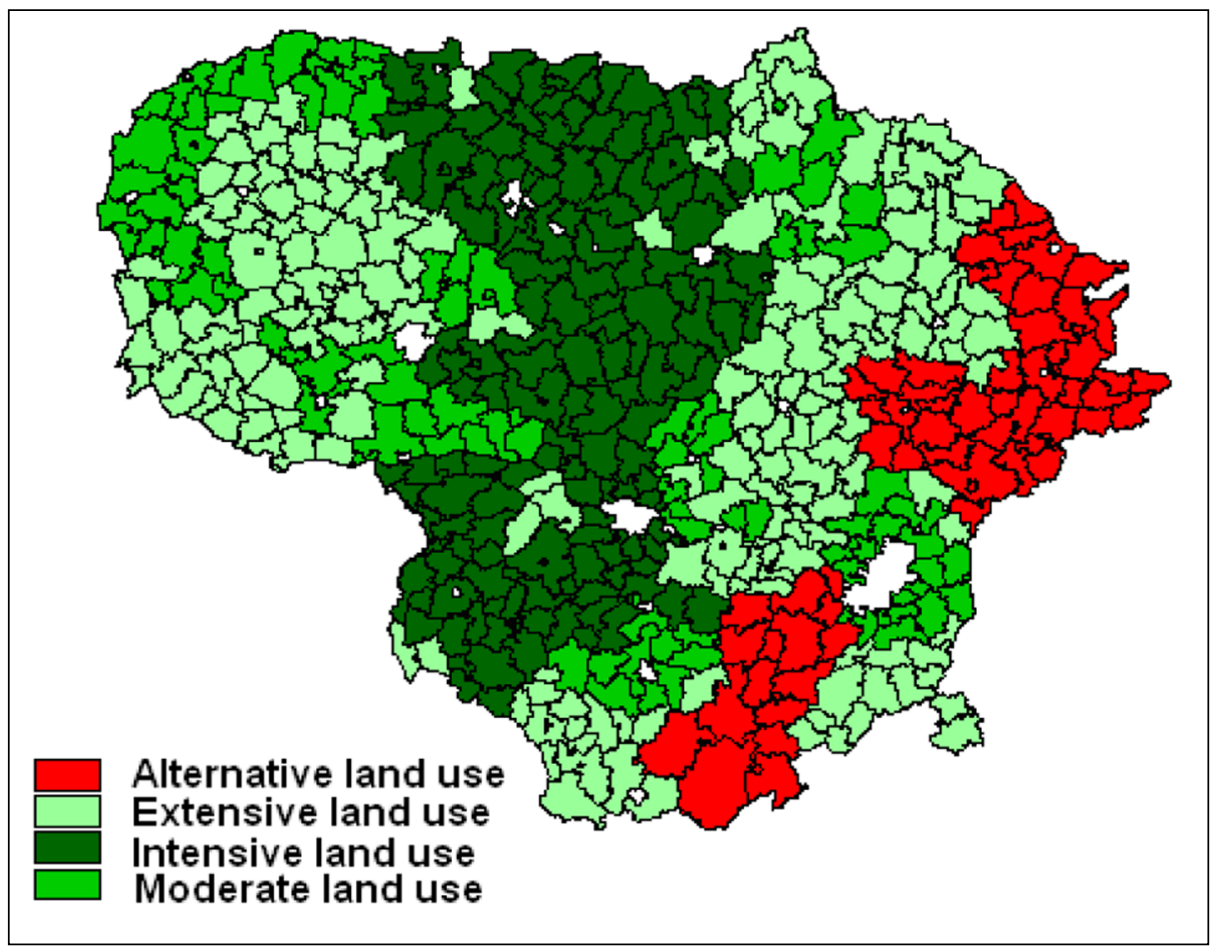

Fig. 3. Subdistrict zoning areas according to their suitability for agricultural development (Concerning..., 2004; The National Strategy Plan..., 2007) 


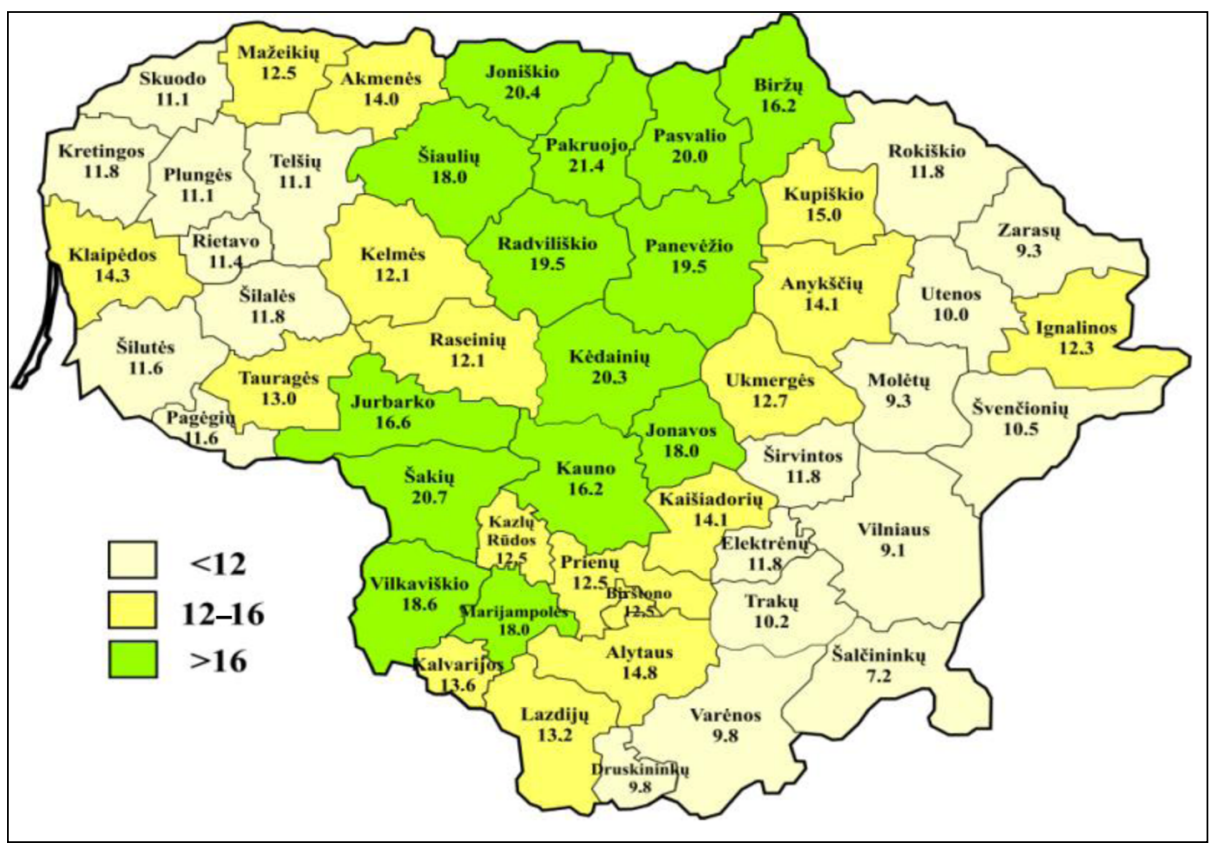

Fig. 4. Lithuanian soil-point increase due to drainage

benefits of land use. The above indicators (at the subdistrict level) are presented in Table 2 .

Having taken into account the wealth of information and the significance of the index, a key economic indicator, determining drained land valuation by the benefits of economic justification for the selected index - profit without subsidies by 1 point, was chosen because it only evaluates the effectiveness of land use, eliminating the influence of additional state support (direct payments per area). Multiplying the profit without subsidies by 1 point value from the potential increase in land productivity due to the drainage points (Fig. 5) corresponds to the average value for money - the profit without subsidies from one hectare obtained for the drainage works carried out. It includes the municipal and subdistrict level.

According to economic indicators and economic benefits in terms of average, drainage of agricultural land can be divided into:

- significant economic benefits (income received in grants over LTL 261/score);

- the average economic benefit (LTL 201-260/ score);

- a small economic benefit (LTL 101-200/score);

- a very little economic benefit (LTL 0-100/ score).

Expediency of the reconstruction of drainage systems is justified by economic indicators of land use. Comparing the above-mentioned economic

Table 2. Land use comparative economic results in the counties of Lithuania (FADN..., 2008)

\begin{tabular}{|c|c|c|c|c|c|c|c|c|c|c|}
\hline \multirow[b]{2}{*}{ Indicators } & \multicolumn{10}{|c|}{ Counties } \\
\hline & 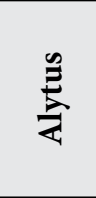 & 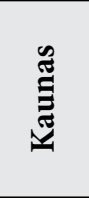 & 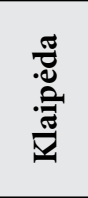 & 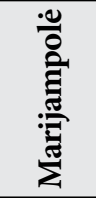 & 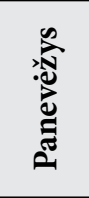 & 漓 & 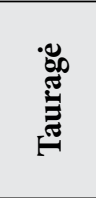 & 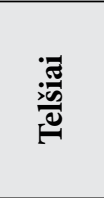 & 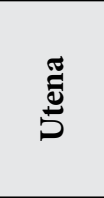 & 晩 \\
\hline Efficiency scores & 34.3 & 44.7 & 37.1 & 44.5 & 44.2 & 45.8 & 36.4 & 31.3 & 32.9 & 33.6 \\
\hline \multicolumn{11}{|c|}{ For 1 agricultural productivity score, LTL } \\
\hline Gross output & 48.50 & 48.66 & 58.42 & 55.62 & 50.20 & 49.78 & 73.08 & 66.49 & 56.83 & 45.74 \\
\hline $\begin{array}{l}\text { The net added value } \\
\text { without subsidies }\end{array}$ & 14.31 & 17.97 & 19.48 & 18.62 & 18.95 & 20.72 & 23.60 & 24.15 & 20.71 & 10.73 \\
\hline Profit without subsidies & 15.26 & 16.29 & 18.93 & 19.61 & 18.76 & 18.51 & 24.89 & 22.42 & 21.48 & 7.54 \\
\hline
\end{tabular}




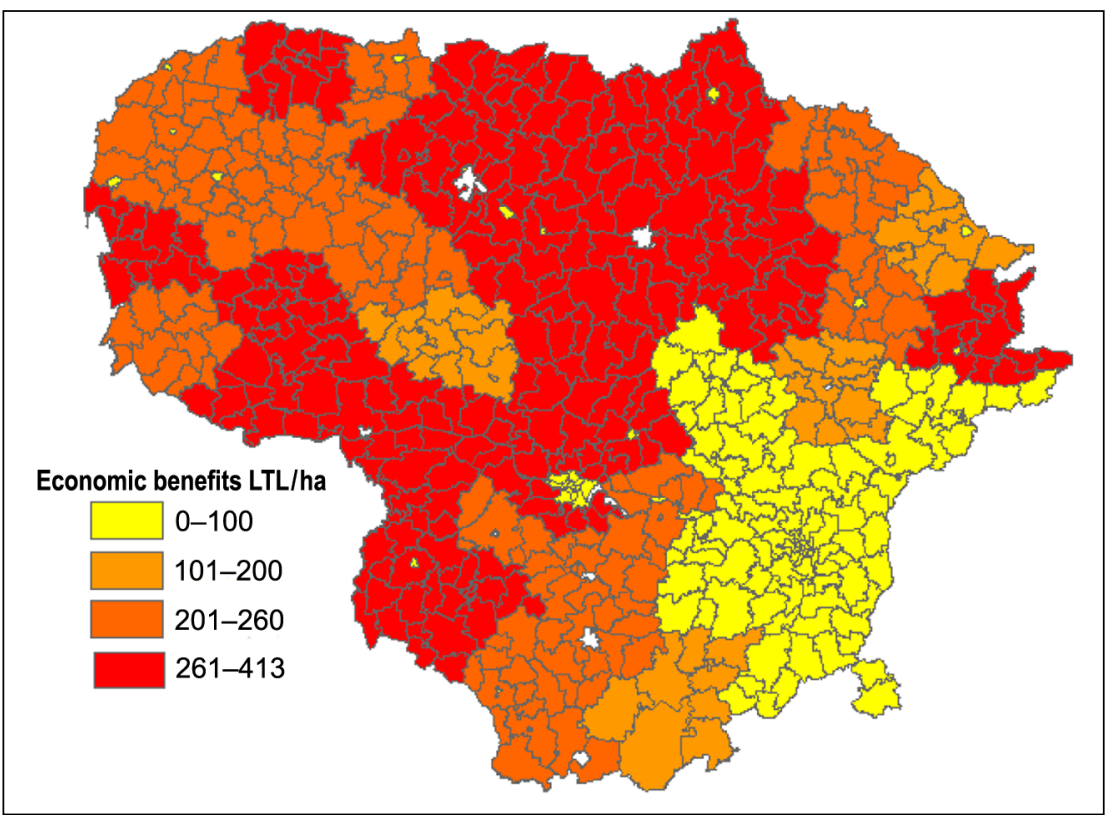

Fig. 5. The economic benefits of land reclamation area

benefits of land with the cost of drainage reconstruction of poor reclamation condition (Economic Normatives..., 2007), the investment will pay off in the following way: very little benefit - 30 years, small -13 years, average -10 years, significant -7 years. The rational tangible return on investment in agriculture is $7-10$ years, so very low
(LTL 0-100/score) and low (LTL 101-200/score) economic benefits of land drainage restoration are not economically feasible.

According to the selected criteria and the significance the subdistricts, in which area it is appropriate or inappropriate to restore drainage systems of poor technical condition, are singled out (Fig. 6).

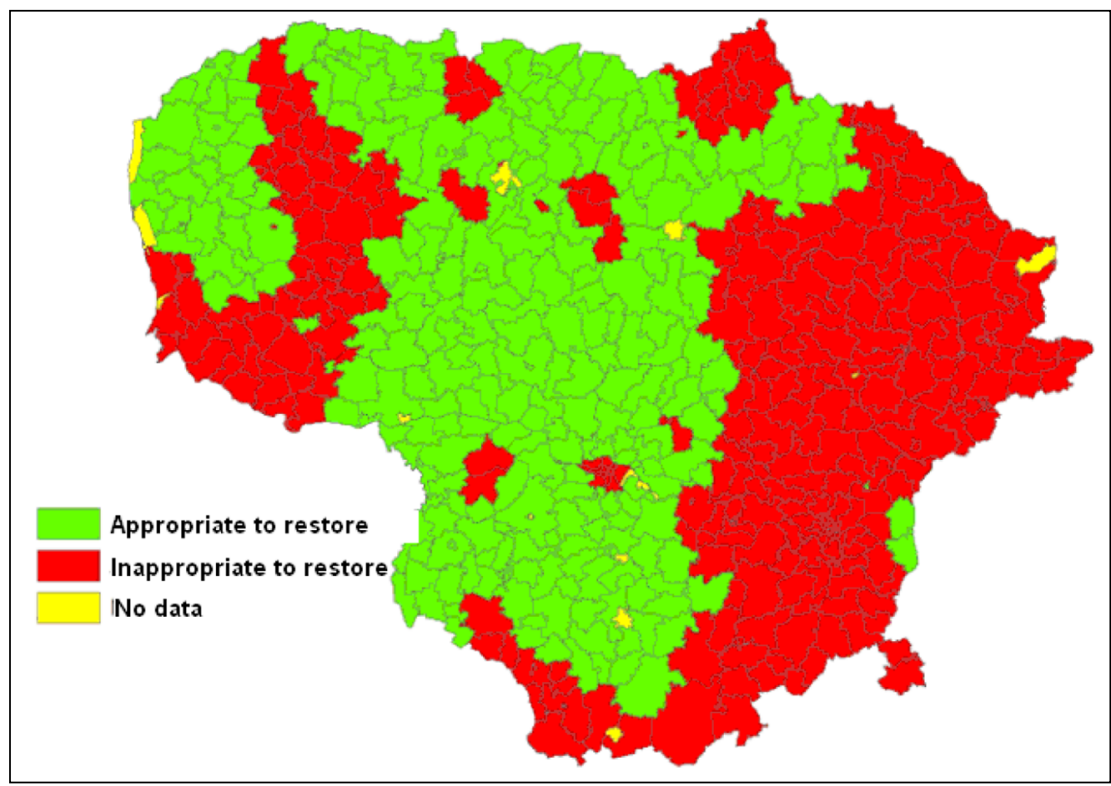

Fig. 6. Expediency of the reconstruction of drainage systems in subdistricts according to their areas of agricultural development strategy and economic benefits received from the drained lands 
In social terms, when assessing the drainage system rehabilitation/renovation operation, or maintenance of expediency, in our opinion, it is necessary to fully assess the specific cases where the individual plots of land with drainage systems of poor condition are used as the primary or sole ground source of income of the user (resident and his family). In such cases, more detailed analysis of the causes of poor reclamation condition is necessary, their consequences should be assessed, possible land use changes considering land user's needs and opportunities should be examined.

\section{CONCLUSIONS}

1. Seven percent of drained areas in Lithuania are of poor reclamation condition because of damaged drainage systems. The expediency of their recovery must be based on strategic, economic and social criteria.

2. Restoration of drainage systems is appropriate in areas, in which an intensive and medium intensity agricultural land use is planned (under the national rural development strategy), and over LTL 200/ha of economic benefits are received (due to drainage).

3 . In assessing the appropriateness of the restoration of drainage systems, the needs of land users and their financial resources must be taken into account.

Received 7 March 2013

Accepted 7 October 2013

\section{REFERENCES}

1. Bastienè N., Buožis V. 2001. The estimation of drainage age as of the factor of failure risk. Water Management Engineering. Vol. 16(38). P. 5-11.

2. Baubinas R. 1997. Transformation of Territorial Processes and Rural Regional Policy in Lithuania.
Scientific, Social and Production Problems of the Use of Environmentally Sensitive and Unfavourable Agricultural Lands in Lithuania when Integrating into the European Union: Scientific Conference Proceedings. Vilnius. P. 24-28.

3. Concerning the Less-Favoured Areas. 2004. Approved by Order No. 3D-287 of the Minister of Agriculture of the Republic of Lithuania of 3 May 2004 (with later amendments and supplements).

4. Database of the Lithuanian Land Melioration Situation and Soaking Mel_DB10LT at Scale 1:10 00. 2008. Environmental Protection Agency. Copyright License Agreement.

5. Economic Normatives of the Estimated Price of Reclamation Facilities (Works). 2007. Approved by Order No. 3D-53 of the Minister of Agriculture of the Republic of Lithuania of 5 February 2007 (in Lithuanian).

6. FADN (Farm Accountancy Data Network) Survey Results. 2008. Vilnius: Lithuanian Institute of Agrarian Economics. 108 p. [cited 2012-04-10]. Available from internet: http://www.laei.lt/?mt =le idiniai\&straipsnis $=16 \&$ metai $=2009$

7. Long-term Development Strategy of the State. 2002. Approved by the Seimas of the Republic of Lithuania under Act No. IX-1187 of November 12, 2002 [cited 2012-04-10]. Available from internet: http://www3.lrs.lt/pls/inter2/dokpaieska. showdoc_l?p_id=193888

8. Maziliauskas A., Morkūnas V., Rimkus Z., Šaulys V. 2007. Economic incentives in land reclamation sector in Lithuania. Journal of Water and Land Development. Vol. 11. P. 17-30.

9. Šaulys V., Bastienè N. 2007. Ecological and Economical Aspects of the Management of Drainage Systems in Lithuania. Rural Development 2007: Scientific Conference Proceedings. Jelgava, Latvia. P. 264-270.

10. The National Strategy Plan for the Period 2007-2013 accepted on July 18, 2007. Available from internet: http://www.zum.lt/documents/kaimo pletros_depart/nsp+lithuania+(2009-06-15).dod

11. The Technical Assessment of the Condition of Reclaimed Lands and Drainage Structures of the Republic of Lithuania. 2007. Vilnius: State Enterprise "State Land Survey Institute". 


\section{Vidmantas Gurklys, Algis Kvaraciejus \\ DRENAŽO SISTEMŲ REKONSTRUKCIJOS \\ TIKSLINGUMAS}

Santrauka

Lietuvoje pagal kilmę drègnos ir pelkètos žemès sudaro apie $3,5 \mathrm{mln}$. ha. Iki $2011 \mathrm{~m}$. šalyje buvo nusausinta $2,98 \mathrm{mln}$. ha drègnų ir užpelkèjusių žemių, iš jų 2,58 mln. ha žemés ūkio naudmenų. Dèl socialinių, demografinių ir ekonominių priežasčių pastaruoju metu šalyje daug apleistų, žemės ūkio gamyboje nebenaudojamų nusausintų žemés plotų, neprižiūrimos sausinimo sistemos. Apie $7 \%$ sausinamų plotų yra blogos melioracinès būklès. Jų atkūrimui reikalingos didelès investicijos, todèl aktualu ịvertinti, ar tikslinga pradèti atstatymo darbus.

Straipsnyje, priklausomai nuo gaunamos ekonominès naudos iš žemès ūkio gamybos ir kaimo plètros strategijos, yra nustatytos teritorijos, kuriose tikslinga / netikslinga atstatyti sausinimo sistemas.

Raktažodžiai: sausinami plotai, bloga melioracinè būklè, atstatymo tikslingumas 